\title{
Role of palmar dermatoglyphics in detecting precancerous lesions
}

\begin{abstract}
Dermatoglyphics is the reflection of DNA. Palmar prints once formed do not change throughout life and can be influenced by environment. Palmar dermatoglyphics can indicate the development of potentially malignant and malignant lesions and help in identifying persons at high risk of developing oral submucous fibrosis (OSMF) and oral squamous cell carcinoma (OSSC).
\end{abstract}

Aim of the study: To analyze the correlation of palmar dermatoglyphics pattern in OSMF, leukoplakia and healthy patients.

Materials and methods: A cross-sectional study comprised of 45 patients which were divided in to four separate groups group i-OSMF consisted of (grade-I,II,III,IV), group IIleukoplakia,group III-habits without lesion,group iv-control group. In all the patients palm prints were recorded using hp scanner and finger tips pattern were recorded using intraoral camera and evaluated using onewayannova test spss $19^{\text {th }}$ version.

Results: Whorls on left hand more common in group iv than in group I,II,III. Whorls on right hand are same in group I,II group less group III. loops are more in group I,II,III, less in group IV.absence of arches seen in group $I$ and ii $6.7 \%$ in group III and $13.3 \%$ in group iv. Mean ATD triangle was less in group I,II,III when compared to group IV. over all $\mathrm{p}$ value is 0.001 .

Conclusion: The individuality of a person's finger prints led to the analysis of one's potential, personality and preferences by analyzing dermatoglyphics.

Keywords: palms, digits, soles, oral mucosa, sharp tooth margins, improper restorations, prosthesis, alcohol, smoking, infants, cerebral palsy, rubella
Volume II Issue I - 2020

\author{
Jayalakshmi B,Avinash Tejasvi ML, Harsha \\ Bhayya, Shilpa J,Vammi Sirisha \\ Department of Oral Medicine and Radiology, Government \\ Dental College, India
}

Correspondence: Jayalakshmi B, Department of Oral Medicine and Radiology, Government Dental College, Hyderabad, Telangana State, India, Email drjayalakshmil992@gmail.com

Received: January 20, 2020 | Published: February II, 2020
Abbreviations: OSSC, oral squamous cell carcinoma; OSMF, oral submucous fibrosis; OSF, Oral submucous fibrosis; OL, oral leukoplakia; PMD, potentially malignant disorder

\section{Introduction}

Cummins \& Midlo $^{1}$ coined the term dermatoglyphics which means (derma=skin; glyphics=carvings), for the scientific study of ridges as well as the ridges themselves Dermatoglyphics is a relatively new science, which involves the study of different patterns of dermal ridges on palms, digits, and soles. ${ }^{2}$

Genetics play most important role in the determination of palmer dermatoglyphics. Oral submucous fibrosis (OSMF) is due to consumption of areca nut. Environmental and Hereditary factors causing OSMF may lead to peculiarities in the dermatoglyphic patterns. Dermatoglyphics can identify the disease at the earliest, and preventive measures can be instituted for subjects having OSMF, leukoplakia etc. ${ }^{3}$

Oral submucous fibrosis (OSF) is a potentially malignant disorder associated with the chewing of areca nut (betel nut). Initially it presents with inflammation followed by hypovascularity and fibrosis visible as blanching of the oral mucosa which may be localized, diffuse, or reticular. In some cases, small vesicles may develop that rupture and form erosions. ${ }^{4}$ Oral leukoplakia (OL) is one among important potentially malignant disorder (PMD) of the oral mucosa. It is defined as "a predominantly white lesion of the oral mucosa that cannot be characterized as any other definable lesion."

Thus, the present study was carried out with the aim to analyze the correlation of palmar dermatoglyphics pattern in OSMF, leukoplakia and healthy patients.

This would give a cost-effective, non invasive, unique approach in screening and identifying the persons who are at risk.

\section{Materials and methods}

A Cross-sectional study was carried out among patients visiting the Department of Oral Medicine and Radiology, Kamineni institute of dental sciences. The ethical clearance was obtained from Institutional Ethical Review Board. Patients were explained in detail about the study, and informed consent was obtained. The total sample size of 45age ranged between 20 to 75 yearswas taken which were divided in to 4 groups Group I-OSMF consisted of Grade I, II, III, IV(10 male patients),Group II Leukoplakia(10 male patients), Group III-Habits without lesion(10 male patients)Group IV-Control group(10 male and 5 female patients).

\section{Inclusion criteria}

The clinically diagnosed cases of oral leukoplakia, OSMF and were confirmed histopathologically and included in the study. 


\section{Exclusion criteria}

a. Presence of oral lesions due to other causes such as sharp tooth margins, improper restorations, prosthesis, alcohol, or smoking.

b. Patients with scars or any injury to digits.

c. Patients with any systemic diseases.

\section{Materials and methods}

Palm prints were recorded after getting the informed consent from study and control groups. All cases the palm prints were recorded using an inkjet scanner (Figure 1). The patients were asked to place the palm on the scanner (Figure 1). After the recording was done, the images of the palm prints were cropped to measure ATD triangle which is formed by joining the points A, T, and D.

Where A indicates triradii point present below the index finger, $\mathrm{T}$ indicates triradii point present in the thinner area and $\mathrm{D}$ indicates triradii point present below the little finger (Figure 2). The angle is measured from the triangle which is formed by joining line from A,T,D. For the first time intraoral camera is used to measure pattern of finger ridge (Figure $3 \& 4$ ).

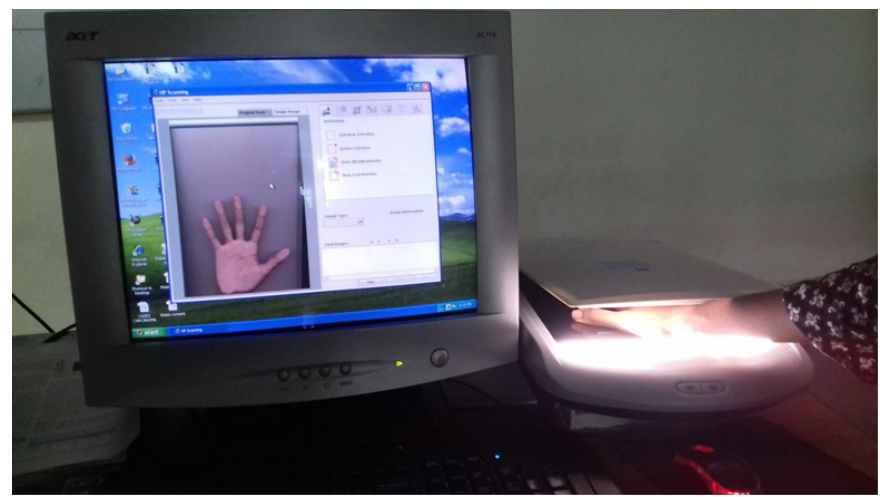

Figure I Palm scan.

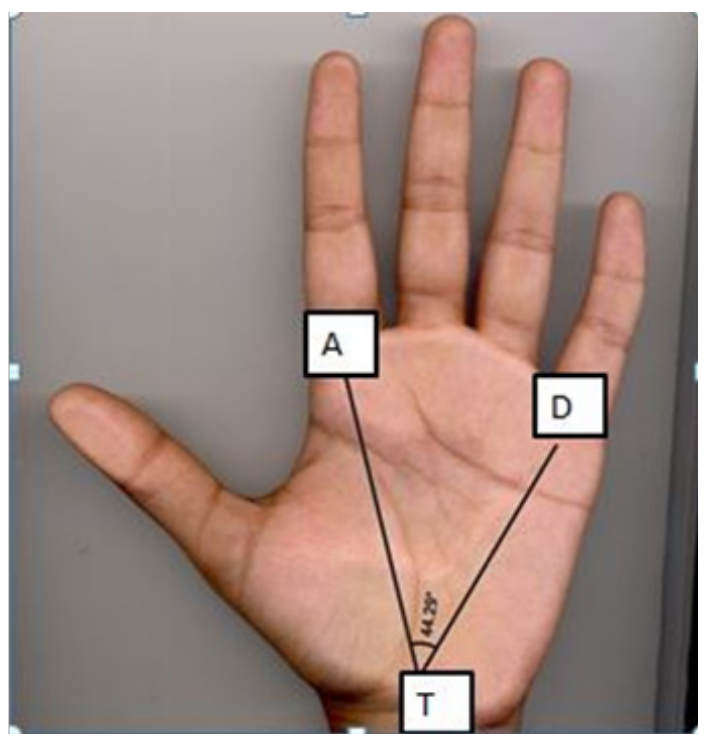

Figure 2 ATD triangle.

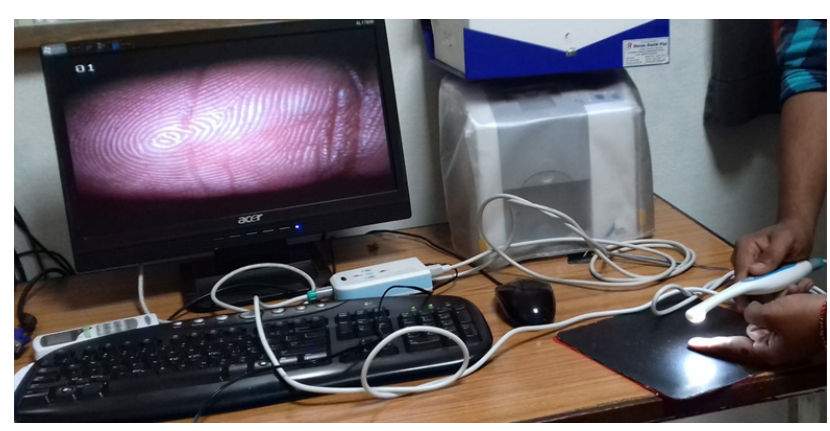

Figure 3 First timeintraoral camera is used to measurepattern of finger ridge.

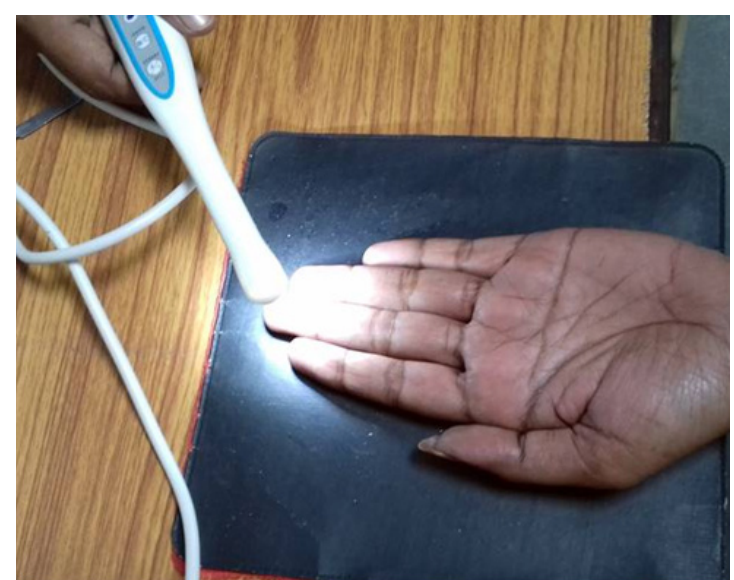

Figure 4 First timeintraoral camera is used to measurepattern of finger ridge.

The finger and palmer prints were analysed qualitatively and quantitatively. Percentages of loops, whorls, and arches were calculated in all the four groups. One way Annova Test was performed .The analyses were performed using SPSS $19^{\text {th }}$ Version.

\section{Results}

In group I percentage of loop on right hand showed $60 \%$, left hand showed $80 \%$ and whorls $40 \%$ on right, $20 \%$ on left hand respectively (Table 1). In group II percentage of loop on right hand showed $60 \%$ and left hand showed $100 \%$ and whorls $40 \%$ on right no whorls were recorded on left hand (Table 2). In group III percentage of loop on right hand showed $60 \%$ and left hand showed $80 \%$ and $20 \%$ of whorls on both hands. $20 \%$ of arches on right hand (Table 3). In group IV the whorl pattern was $40 \%$ and $46.7 \%$ in right and left hand, respectively. Loop pattern was $53.3 \%$ and $40 \%$ in right and left hand, respectively. Arches pattern was $6.7 \%$ and $13.4 \%$ in right and left hand, respectively (Table 4). Mean ATD triangle of OSMF patients was 38.336 and 39.128 right and left hand, respectively (table5). Mean ATD triangle of leukoplakia was 39.734 and 38.91 right and left hand, respectively (Table 6). Mean ATD triangle of habits without lesion was 36.946and 34.76691 right and left hand, respectively (Table 7). Mean ATD triangle of control group was 41.12333333 and 41.484 right and left hand, respectively (Table 8). Comparison of finger ridge pattern in among study groups of Right Hand (Table 9). Comparison of finger ridge pattern in Among Study groups of left hand (Table 10). Comparison of ATD Triangle among the study groups right hand 
(Table 11). Comparison of ATD Triangle among the study groups left hand (Table 11). In our study over all $\mathrm{P}$ value-0.01 was (significant). Comparison between Group I and Group IV-0.25 (not significant).
Comparison between Group II and Group IV-0.51 (not significant). Comparison between Group III and Group IV-0.71 (significant).

Table I Group I oralsubmucous fibrosis

\begin{tabular}{llllll}
\hline & \multicolumn{2}{c}{ Ridge pattern (right) } & \multicolumn{2}{c}{ Ridge pattern (left) } \\
\hline Type of ridge & Frequency & Percentage & Type of ridge & Frequency & Percentage \\
\hline Whorl & 4 & 40 & Whorl & 2 & 20 \\
Loop & 6 & 60 & Loop & 8 & 80 \\
Total & 10 & 100 & Total & 10 & 100 \\
\hline
\end{tabular}

Table 2 Group II leukoplakia

\begin{tabular}{llllll}
\hline & \multicolumn{2}{c}{ Ridge pattern (right) } & \multicolumn{2}{c}{ Ridge pattern (left) } \\
\hline Type of ridge & Frequency & Percentage & Type of ridge & Frequency & Percentage \\
\hline Whorl & 4 & 40 & Whorl & 0 & 0 \\
Loop & 6 & 60 & Loop & 10 & 100 \\
Total & 10 & 100 & Total & 10 & 100 \\
\hline
\end{tabular}

Table 3 Group III habits without lesion

\begin{tabular}{|c|c|c|c|c|c|}
\hline \multicolumn{3}{|c|}{ Ridge pattern (right) } & \multicolumn{3}{|c|}{ Ridge pattern (left) } \\
\hline Type of ridge & Frequency & Percentage & Type of ridge & Frequency & Percentage \\
\hline Whorl & 2 & 20 & Whorl & 2 & 20 \\
\hline Loop & 6 & 60 & Loop & 8 & 80 \\
\hline ARCHES & 2 & 20 & ARCHES & 0 & 0 \\
\hline Total & 10 & 100 & Total & 10 & 100 \\
\hline
\end{tabular}

Table 4 Group IV control group

\begin{tabular}{llllll}
\hline & \multicolumn{2}{c}{ Ridge pattern (Right) } & \multicolumn{2}{c}{ Ridge pattern (Left) } \\
\hline Type of ridge & Frequency & Percentage & Type of ridge & Frequency & Percentage \\
\hline Whorl & 6 & 40 & Whorl & 7 & 46.7 \\
Loop & 8 & 53.3 & Loop & 6 & 40 \\
ARCHES & I & 6.7 & ARCHES & 2 & 13.3 \\
Total & I5 & 100 & Total & 15 & 100
\end{tabular}

Table 5 Mean ATD Triangle of OSMF patients

\begin{tabular}{lllll}
\hline \multicolumn{4}{c}{ Mean ATD triangle of OSMF patients } \\
\hline Mean of right ATD & SD & Mean of left ATD & SD \\
\hline 38.336 & 2.473576 & 39.128 & 3.818366 \\
\hline
\end{tabular}


Table 6 Mean ATD triangle of leukoplakia

\begin{tabular}{llll}
\hline \multicolumn{3}{l}{ Mean ATD triangle of leukoplakia } & \\
\hline Mean of right ATD & SD & Mean of left ATD & SD \\
\hline 39.734 & 4.195525 & 38.91 & 4.096 \\
\hline
\end{tabular}

Table 7 Mean ATD triangle of habits without lesion

\begin{tabular}{llll}
\hline \multicolumn{4}{l}{ Mean ATD triangle of habits without lesion } \\
\hline Mean of right ATD & SD & Mean of left ATD & SD \\
\hline 36.946 & 3.261262 & 34.766 & 3.510125 \\
\hline
\end{tabular}

Table 8 Mean ATD triangle of control group

\begin{tabular}{lccc}
\hline \multicolumn{4}{c}{ Mean ATD triangle of control group } \\
\hline Mean of right ATD & SD & Mean of left ATD & SD \\
\hline 41.12333 & 3.394268 & 41.484 & 3.752736 \\
\hline
\end{tabular}

Table 9 Finger ridge pattern among study groups of right hand

\begin{tabular}{|c|c|c|c|c|c|c|c|c|c|}
\hline & Osmf patients & & Leukoplakia patients & & Habits Without lesions & & Control group & & \\
\hline & frequency & $\%$ & frequency & $\%$ & frequency & $\%$ & frequency & $\%$ & $\begin{array}{l}P \\
\text { value }\end{array}$ \\
\hline Whorls & 4 & 40 & 4 & 40 & 2 & 20 & 6 & 40 & 0.998 \\
\hline Loops & 6 & 60 & 6 & 60 & 6 & 60 & 8 & 53.3 & 0.999 \\
\hline Arches & 0 & 0 & 0 & 0 & 2 & 20 & 1 & 6.7 & 0.9 \\
\hline Total & 10 & 100 & 10 & 100 & 10 & 100 & 15 & 100 & - \\
\hline
\end{tabular}

Table 10 Finger ridge pattern among study groups of left hand

\begin{tabular}{|c|c|c|c|c|c|c|c|c|c|}
\hline & \multicolumn{2}{|c|}{ Osmf patients } & \multicolumn{2}{|c|}{ Leukoplakia patients } & \multicolumn{2}{|c|}{ Habits without lesions } & \multicolumn{2}{|c|}{ Control group } & \multirow[b]{2}{*}{$P$ value } \\
\hline & Frequency & $\%$ & Frequency & $\%$ & Frequency & $\%$ & Frequency & $\%$ & \\
\hline & 2 & 20 & 0 & 0 & I & 20 & 7 & 46.7 & 0.93 \\
\hline \multicolumn{10}{|l|}{ Whorls } \\
\hline Loops & 8 & 80 & 10 & 100 & 4 & 80 & 6 & 40 & 0.99 \\
\hline Arches & 0 & 0 & 0 & 0 & 0 & 0 & 2 & 13.3 & 0.93 \\
\hline Total & 10 & 100 & 10 & 100 & 10 & 100 & 15 & 100 & \\
\hline
\end{tabular}

Table I I ATD Triangle among the study groups right hand

\begin{tabular}{|c|c|c|c|c|c|c|c|c|c|}
\hline & \multicolumn{2}{|c|}{ Osmf patients } & \multicolumn{2}{|c|}{ Leukoplakia patients } & \multicolumn{2}{|c|}{ Habits without lesions } & \multicolumn{2}{|l|}{ Control group } & \multirow[b]{2}{*}{$\begin{array}{l}P \\
\text { value }\end{array}$} \\
\hline & Mean士sd & $\begin{array}{l}\text { Minimum- } \\
\text { Maximum }\end{array}$ & Mean \pm sd & $\begin{array}{l}\text { Minimum- } \\
\text { Maximum }\end{array}$ & Mean士sd & $\begin{array}{l}\text { Minimum- } \\
\text { Maximum }\end{array}$ & Mean \pm sd & $\begin{array}{l}\text { Minimum- } \\
\text { Maximum }\end{array}$ & \\
\hline $\begin{array}{l}\text { ATD } \\
\text { Triang| }\end{array}$ & $38.336 \pm 2.47$ & $34.45-41.09$ & $39.734 \pm 4.19$ & $36.43-46.97$ & $36.946 \pm 3.26$ & $31.75-40.42$ & $41.12333333 \pm 3.39$ & $35.5-46.05$ & 0.01 \\
\hline
\end{tabular}




\section{Discussion}

Greek derma=skin, glyph=carving) is the study of fingerprints, mounts, lines and shapes of hands. Dermatoglyphic patterns can deviate from normal in a wide array of disorders like.

A. Autosomal aneuploidy such as, trisomy 18, mongolism and trisomy 15.

B. Chromosomal disorders such as Turner's syndrome, Klinefelter syndrome.

C. Single Gene Disorders like Wilson's disease, Huntington's chorea.

D. Disorders with uncertain genetic transmission such as idiopathic mental retardation, congenital heart disease, psoriasis.

E. Exogenous influences such as thalidomide damaged infants, cerebral palsy, rubella.

Cummins and Midlo classified various pattern types on fingertips as: ${ }^{7}$
a. Arch.
b. Loop.
c. Whorl.
d. Composites.

Oral squamous cell carcinoma is a common malignancy encountered oral malignant tumor. Its etiology is multifactorial most important are tobacco and alcohol, separately and synergically. ${ }^{8,9}$ OSMF is a premalignant condition, and areca nut exposure is the major determinant of OSMF. ${ }^{10}$ Since only a fraction of exposed persons develop cancer, an intrinsic susceptibility of an individual to environmental genotoxic exposures was also been suggested as playing a role in carcinogenesis. ${ }^{10}$

\section{In our study we observed the following}

On observing the fingertips using intraoral camera, there was increased frequency of loops in patients with OSMF and leukoplakia, habit without lesion as compared to controls who have whorls as the frequent pattern. Venkatesh et al., ${ }^{11}$ Gupta et al., ${ }^{12}$ and David \& Sinha ${ }^{13}$ stated that there was a significant increase of loops in study groups which is similar with our study. Arch pattern was noticed in group 3 and 4 while absent in the leukoplakia and OSMF group.

A study done by Ganvir \& Gajbhiye ${ }^{14}$ found an increased frequency of whorls in cases which were inconsistent with our results. ATD angle in patients with habits without lesions when compared with the controls showed similar results whereas there is a decrease in the ATD angle in OSMF when compared with the controls and increased in leukoplakia patients. Our study showed differences in the dermatoglyphic patterns among various groups which could be considered as genetic markers for early detection of OSMF, leukoplakia.

\section{Conclusion}

The field of dermatoglyphics holds very good promising results for determining the genetic susceptibility of individuals to develop leukoplakia, OSMF. The present study shows significant results. The advantage with Dermatoglyphics is cost burden with genetic cytomarkers may be prevented. Thus, with the help of simple measurements, simple technique the frequency of developing diseases in later life may be prevented. Further studies are required for the evaluation of dermatoglyphics pattern with in different grades of oral submucous fibrosis and stages oral cancer.

\section{Funding details}

None.

\section{Acknowledgments}

None.

\section{Conflicts of interest}

The authors declare that there is no conflicts of interest.

\section{References}

1. Cummins H, Midlo C. Fingerprints, Palms and Soles: An Introduction to Dermatoglyphics. New York: Dover Publication Inc.; 1961.

2. Schaumann B, Alter M. Dermatoglyphics in medical disorders. New York: Springer Verlag; 1976.

3. Shetty P, Shamala A, Murali R, et al. Dermatoglyphics as a genetic marker for oral submucous fibrosis: A cross-sectional study. Journal of Indian Association of Public Health Dentistry. 2016;14(1):41.

4. Wollina U, Verma SB, Ali FM, et al. Oral submucous fibrosis: an update Clinical, Cosmetic and Investigational Dermatology. 2015;8:193.

5. Warnakulasuriya S, Johnson NW, van der Waal I. Nomenclature and classification of potentially malignant disorders of the oral mucosa. J Oral Pathol Med. 2007;36(10):575-580.

6. Alter M. Dermatoglyphic analysis as a diagnostic tool. Medicine (Baltimore). 1967;46(1):35-56.

7. Napier SS, Speight PM. Natural history of potentially malignant oral lesions and conditions: an overview of the literature. J Oral Pathol Med. 2008;37(1):1-10.

8. Scully C. Oral cancer aetiopathogenesis; past, present and future aspects Med Oral Patol Oral Cir Bucal. 2011;16(3):e306-11.

9. Vinothini G, Sarvathikari R, SakthivelSambasivam J, et al. Evaluating the Relation Between Palmar Detmatoglyphics with Submucous Fibrosis and Squamous Cell Carcinoma of the Oral Cavity. International Journal of Advanced Health Sciences. 2017;4(1):1-7.

10. Barón AE, Franceschi S, Barra S, et al. A comparison of the joint effects of alcohol and smoking on the risk of cancer across sites in the upper aerodigestive tract. Cancer Epidemiol Biomarkers Prev. 1993;2(6):519-23.

11. Venkatesh E, Bagewadi A, Vaishali K, et al. Palmar dermatoglyphics in oral leukoplakia and oral squamous cell carcinoma patients. J Indian Acad Oral Med Radiol. 2008;20(3):94-99.

12. Gupta A, Karjodkar FR. Role of dermatoglyphics as an indicator of precancerous and cancerous lesions of the oral cavity. Contemp Clin Dent. 2013;4(4):448-453.

13. David P, Sinha P. Dermatoglyphic patterns in subjects with potentially malignant disorders and oral carcinoma. Maria J Adv Clin Res Insights. 2015;2:7-11.

14. Ganvir SM, Gajbhiye NY. Detection of genetic predisposition in oral squamous cell carcinoma (OSCC) and oral submucous fibrosis patients by qualitative analysis of finger and palm-print patterns: A dermatoglyphic study. Clin Cancer Investig J. 2014;3(5):377-382. 